\title{
“¡Y NO SE RÍEN DE ESTE LESO PORQUE ES DUEÑO DE MILLONES!": EL ASEDIO CÓMICO Y POPULAR DE JUAN RAFAEL ALLENDE A LA BURGUESÍA CHILENA DEL SIGLO XIX
}

La historia de las elites decimonónicas ha sido contada como la historia de un Olimpo tan elevado e inalcanzable como serio. Juan Rafael Allende logró en el mismo siglo XIX crear un mundo paralelo si no alternativo que derribó tanta sospechosa sublimidad. El gran autor satírico se hizo cargo del habla histórica de la plebe chilena que provenía en alguna medida de la Picaresca española de los siglos XVI y XVII con su anticlericalismo y su anticapitalismo visceral y carnavalesco. Prolongando este mundo al siglo XIX Allende lo convirtió en una dinamita contra la gravedad del Estado y del Mercado 'en forma'. En particular, fueron atacados insignes representantes de la burguesía chilena como Eduardo Matte, Manuel José Irarrázaval, Agustín Edwards, Julio Zegers o Federico Varela. Ellos habían creado una nueva religión del dinero que Allende se apresuró a denunciar como una burda parodia del Dios cristiano. Había nacido en el país un nuevo credo, el "credo de los salitreros". El origen del pensamiento satírico de Allende tiene larguísimas raíces de las que no podemos obviar, además de la mencionada Picaresca, la tradición de la España hispano-árabe, que se rió de ricos y magnates en el mejor espíritu del Libro del Buen Amor y sus antecedentes musulmanes.

Palabras clave: Humor, burguesía chilena, crítica social, Juan Rafael Allende.

The history of Chile's 19th-century elites has been narrated as an Olympian story: lofty, unreachable and grave. During the same century, writer Juan Rafael Allende managed to create a parallel, if not alternative world which demolished such suspect sublimity. The great satiric author appropriated Chile's historic plebeian speech, somehow descended from the Spanish picaresque of the 16th and 17th centuries, adopting its visceral and carnival-like anti-clericalism and anticapitalism. Projecting this mode into the 19th century, Allende turned it into a weapon to be used against the gravitas of the formal Market and State. In particular, his attacks were leveled against renowned members of the Chilean bourgeoisie, such as Eduardo Matte, Manuel José Irarrázaval, Agustín Edwards, Julio Zegers or Federico Varela. They had framed a new wealth-centered religion

* Profesor del Departamento de Historia de la Universidad de Santiago de Chile. Correo electrónico: merquen@gmail.com

1 Este trabajo es fruto del Proyecto FONDECYT 1030092 [2003-2004]: Cultura cómica y sensibilidad popular: la prensa satírica y democrática de Juan Rafael Allende en Chile 1875-1903. Una primera versión de este texto fue presentada en el VIII Congreso de la Sociedad Internacional de Estudios del Humor Luso-Hispano en la Universidad Nacional Autónoma de México, Ciudad de México, 13-15 de octubre de 2004. 
which Allende hastened to denounce as a crass parody of the Christian God. The country had engendered a new creed, the "nitrate-owners creed". The roots of Allende's satirical thought sank deeply into the past, encompassing not only the Spanish Picaresque but also the ancient tradition of Arabic Spain, which made fun of wealthy men and magnates in the best spirit of the Libro del Buen Amor and its Islamic antecedents.

Key words: Humor, chilean bourgeoisie, social criticism, Juan Rafael Allende.

\section{UNA VISIÓN SATÍRICA DE LA HISTORIA POLÍTICA Y SOCIAL CHILENA DEL SIGLO XIX}

"Si el Redentor volviera al mundo y pasara por Chile, no se entendería con los ricos ni con los clericales, que serían los primeros en crucificarlo".

El Padre Padilla, 22.11.1888.

"No echeis a chanza ninguna cosa verdaderamente importante; no lanceis sátiras que puedan ofender, y si decís una palabra espiritual, una palabra chistosa, que no sea a expensas de nadie... Cuando vuestros superiores hablen con alguien, no escucheis, ni os mezcleis en la conversación, ni digáis sátiras”.

José Bernardo Suárez, Compendio de moral y urbanidad, Talca 1890, 34, 37.

La historia política y social de Chile en el siglo XIX ha sido presentada por el pensamiento de las elites como un proceso lineal, ejemplar, fundacional, legítimo. Se ha visto esta historia como el tiempo de los héroes, de los fundadores, de los padres de la patria, de las vidas ejemplares. Este ha sido el lenguaje político del poder, el lenguaje del poder político. Esta forma de hablar apunta al mundo de la 'razón de Estado', al sentido de la historia como despliegue de la lógica expansionista de Occidente, a saber, la historia de los poderosos contra los débiles (=historia de la Guerra), la historia de los civilizados contra los bárbaros (=historia de la Razón), y, más que nada, la historia de los ricos contra los pobres (=historia del Capitalismo). Esta visión de las cosas quedó expuesta desde el mismo siglo XIX a través de una monumentalidad ciudadana característica. La elite santiaguina levantó, entre otras, cuatro estatuas claves en el centro cívico de la ciudad, entre 1860 y 1904. La primera fue dedicada a Diego Portales, como héroe del poder de los ricos, mezcla de Zeus y Mercurio criollo, en 1860. Al descubrirse su efigie se lo ensalzó como aliado del clero y de los "capitalistas"2. La segunda fue dedicada en 1872 a Bernardo O’Higgins como héroe de la guerra, ícono de los poderosos contra los débiles e

2 Discurso de Miguel de la Barra en la inauguración del monumento a Diego Portales, El Ferrocarril, 22.9.1860. 
incapaces, dios Marte criollo. La tercera estatua fue levantada a Andrés Bello: héroe de la razón, la ley y la mesura, suerte de dios Apolo, en 1881. Finalmente se erigió la estatua en memoria de Manuel Montt, héroe del Estado y del 'progreso material', el comercio y la riqueza, embutido también de Zeus y Mercurio mapochino, en 1904. Los cuatro pasaron a ser los arquetipos de la dominación oligárquica del siglo XIX ${ }^{3}$.

Estos héroes o arquetipos de la polis republicana y... masculina continuaron siendo ejemplares hasta fines del siglo XX. Patricio Aylwin llegó a La Moneda -detrás de Augusto Pinochet- inspirado en las figuras de Bernardo O’Higgins y Andrés Bello ${ }^{4}$. Estos héroes o dioses del Olimpo político chileno no tuvieron nada que ver con la sátira ni el buen humor. Al contrario, ellos desterraron la sátira de la polis. El poder político del Estado nacional fue anticómico. Andrés Bello no sabía reír. Así lo recordó José Victorino Lastarria: “Otra cualidad característica de don Andrés era la seriedad. Era moralmente seco y no manifestaba jamás sus impresiones. Su risa parecía una contracción puramente facial" 5 . Andrés Bello no soportó a cómicos como Aristófanes: "Nada tan asqueroso en todos sentidos como las gracias con que Aristófanes sazona a menudo sus versos"6. No olvidemos que Aristófanes fue autor de una sátira política contra la guerra y a favor de la paz, inspirándose en otros dioses, como Dionisos ${ }^{7}$. Manuel Montt tuvo la triste fama de no haber reído nunca, como lo dijera su amigo Domingo Faustino Sarmiento. Los políticos cercanos a Montt reprobaron incluso la literatura cómica de un clásico de la literatura española como Tirso de Molina ${ }^{8}$. Bernardo O'Higgins fue la encarnación del estadista distante del pueblo, frío, grave, despiadado con sus enemigos, entre ellos los seguidores jaraneros del carnaval en Chile ${ }^{9}$. Y Diego Portales fue el

3 Sobre estos arquetipos de sentido histórico de la vida de Occidente, cfr. Franz K. Mayr, $L a$ mitología occidental, Barcelona 1989. Para una visión histórica de la burguesía latinoamericana del siglo XIX, E. Florescano ed., Orígenes y desarrollo de la burguesía en América Latina 1700-1955, México 1985.

4 "Cuando entré por primera vez al palacio de la Moneda como presidente de la República, vi en sus paredes los retratos de nuestros grandes estadistas y escogí a dos para tener cerca mío: el del joven O’Higgins y el del sabio Andrés Bello. Ellos representan para mí los dos cauces más valiosos de nuestra historia... Queremos una historia con la audacia y valentía de O'Higgins y con la solidez y sabiduría de Bello.", Patricio Aylwin, La transición chilena. Discursos escogidos 1990-1992, Santiago 1992, 105-106.

Armando Donoso, Recuerdos de cincuenta años, Santiago 1947, 37.

6 Andrés Bello, Historia de las literaturas de Grecia y Roma, 41. Un discípulo de Bello, Diego Barros Arana criticó por 1o mismo a Quevedo: "Desgraciadamente, extremado en todo, Quevedo no sabe guardar en la elección de sus burlas la mesura del buen gusto, de la decencia,... Quevedo no ha querido contenerse siempre en los límites de la naturalidad y del buen gusto, y frecuentemente ha llevado la caricatura hasta el exceso.", Diego Barros Arana, Elementos de literatura. Historia literaria, Santiago 1893, 290-291.

7 En Los Acarnienses, el héroe cómico Diceópolis, 'Justa Ciudad', es un campesino devoto de Dionisos que se opone al partido belicista de la guerra del Peloponeso, cfr. Aristófanes, Los Acarnienses, Madrid 1996, 22-78.

8 Maximiliano Salinas, Daniel Palma, Christian Báez, Marina Donoso, El que ríe último. Caricaturas y poesías en la prensa humorística chilena del siglo XIX, Santiago 2001, 23-24.

9 "El general O'Higgins conservaba siempre algo de la frialdad y la mesura del gentleman inglés”, Benjamín Vicuña Mackenna, Vida de Bernardo O’Higgins, Santiago 1882, 895; “Tomó de los ingleses su gravedad, su espíritu aristocrático, su puritanismo aparente de costumbres,...”, Miguel Luis Amunátegui, La dictadura de O'Higgins, Santiago 1853, 41. Su lucha contra el Carnaval, Maximiliano Salinas, “En tiempo de chaya nadie se enoja!: la fiesta popular del Carnaval en Santiago de Chile 1880-1910", en Mapocho 50, 2001, 281-325. 
modelo del estadista -o déspota ilustrado- que persiguió la cultura y la fiesta popular y que exijió el derramamiento de sangre para la mantención del orden público $^{10}$.

Portales, O’Higgins, Bello y Montt, símiles de Zeus, Marte, Apolo y Mercurio en el Olimpo chileno, héroes beneméritos de la Ilustración en los valles andinos de Chile, constituyen una galería de estadistas que impusieron una adhesión irrestricta a la gloriosa expansión de Occidente en el siglo XIX. Todos ellos fueron partidarios explícitos de la influencia militar, económica y cultural de Gran Bretaña, la potencia imperialista del momento, con el objeto de elogiar e identificar a los chilenos como "los ingleses de América del Sur". Estos hombres de Estado tuvieron que ser - por lo mismo- serios, "seriotes", como diría Gabriela Mistral, y aun peor que "tontos graves"11. Al fin el Estado oligárquico -como dijo José Victorino Lastarria en 1868- estaba matando no solo la libertad sino la alegría del pueblo: "Un gobierno omnipotente y represivo ha dominado durante treinta y seis años,... hasta sofocar toda muestra de espontaneidad y alegría en el pueblo"12.

El mundo de la elite partidario del Occidente decimonónico, junto con imponer un estilo de vida oligárquico y antipopular, reveló un ethos por completo falto de humor. Y esto -como dejamos dicho- se notó en las formas de hacer política y cultura desde las elites hasta terminar el siglo XX en Chile. Fue la vieja herencia de los "futres" de la Ilustración, o de lo que quedó de ella. Desde una perspectiva explícitamente no elitista, nos interesa ahora relevar la importancia de una visión cómica de la historia política y social chilena. Ella nos permite desestructurar la linealidad del canon antidemocrático de la República del siglo XIX. Para ello recurrimos a la tradición satírica de Juan Rafael Allende. Él criticó a su modo a los próceres de la Ilustración ya nombrados. Por de pronto, se rió de las graves y severas estatuas santiaguinas de Andrés Bello y de Manuel Montt; y de las "momias del monttvarismo". Andrés Bello, para él, estaba "Penando en mármol"13. Montt y su ministro Varas fueron para el autor satírico más que nada las "sanguinarias figuras del fatídico decenio"14.

10 Bernardino Bravo Lira, Portales. El hombre y su obra. La consolidación del gobierno civil, Santiago 1989, 445.

11 "Este aspecto de no presentar en su semblante la sonrisa o hilaridad común al familiar, le daba o valía la clasificación de reservado;...", Miguel Luis Amunátegui R., Don Bernardo O’Higgins juzgado por algunos de sus contemporáneos, RchHG XXIV, 28, 1917, 43. Hay opiniones populares que dicen hoy de O’Higgins: "Ahí hay el mayor ejemplo de hombre triste que va más allá del tonto grave. El tonto grave es serio pero no triste, y este hombre es triste.", Maximiliano Salinas, En el chileno el humor vive con uno, Santiago 1998, 122.

12 Citado en Maximiliano Salinas et al., El que ríe último..., Santiago 2001, 27-28.

13 Sobre Andrés Bello compuso el poema satírico "Penando en mármol": "Tomando el sol, frente al Congreso, / Y haciendo tu difícil digestión, / Cabizbajo estuviste y patitieso, / Espuesto a una tremenda insolación. / Los que de frente, o bien, de medio lado / Contemplaban ese aire monacal, / Decían: 'Don Andrés está taimado, / Se ha roto la columna vertebral. ....”, El Padre Padilla, 4.4.1889. La sátira a la estatua de Manuel Montt, en Maximiliano Salinas et al., El que ríe último..., Santiago 2001, 81-82. Sobre las "momias del monttvarismo", El Padre Padilla, 27.11.1886.

$14 \quad$ El Padre Padilla, 14.7.1888. 


\section{LA APARICIÓN DE UNA COMICIDAD PICARESCA EN EL SANTIAGO BURGUÉS DEL SIGLO XIX: JUAN RAFAEL ALLENDE}

Juan Rafael Allende introdujo durante la segunda mitad del siglo XIX en la ciudad de Santiago una forma de literatura picaresca y bufonesca que alteró los códigos del habla seria de la Ilustración, tal como la pretendiera el mundo ordenado y burgués de Bernardo O'Higgins, Diego Portales, Andrés Bello y Manuel Montt. ¿De dónde surgió esta habla potente, desenfadada y burlesca? Ella tuvo que ver con los códigos más profundos del habla popular chilena, conformada durante los siglos XVI, XVII y XVIII. En el siglo XIX este lenguaje se disparó en contra de un Estado oligárquico que, disfrazado de republicano, progresista y democrático, mantuvo las formas arquetípicas de dominación absolutista propias de la Corona española.

Se trató de un lenguaje proveniente de la Picaresca española de los siglos XVI y XVII donde el mundo se vio desde la risa, el hambre, la protesta social, la situación de los desposeídos, la degradación de los valores de la sociedad establecida. Allí se expresó la denuncia sin tapujos de la penuria económica, el rechazo demoledor de la vida de las elites autodefinidas como nobles, la risa escarnecedora ${ }^{15}$.

La literatura picaresca expresó con desenfado la visión del mundo desde los pobres, con violentas requisitorias anticapitalistas contra el dinero, la banca y los negocios, como podemos encontrar en el Guzmán de Alfarache. El pensamiento picaresco, que se desvaneció en España después de Quevedo, y que se desterró más tarde con la mitología de la Ilustración a partir del siglo XVIII, se mantuvo vigoroso en el habla chilena colonial, y alcanzó esta expresión contestataria en el lenguaje de Juan Rafael Allende durante la segunda mitad del siglo XIX. ${ }^{16}$ En él encontramos otras expresiones clásicas del habla picaresca como "el anticlericalismo desbocado, agresivo y total" del Lazarillo de Tormes en el siglo XVI ${ }^{17}$. Hallamos también la reivindicación del pobre, del vagabundo, del 'deshonrado', en particular en el caso chileno, del "roto". ${ }^{18}$ La clara y tajante división de la sociedad entre ricos y pobres que planteó Allende tiene una relación evidente con la literatura picaresca. La pícara Justina dijo a principios del siglo XVII: "En España, y aun en el mundo, no hay sino sólo dos linajes: el uno se llama el tener, y el otro no tener."19 Allende dirá por su parte: "No me cansaré de repetirlo: en Chile no hay más que dos partidos: el de los ricos, que viven a costillas del trabajo de los pobres, y el de los pobres, que trabajan para los ricos" 20 .

15 José Antonio Maravall, La literatura picaresca desde la historia social (siglos XVI y XVII), Madrid 1986.

16 Maurice Molho, Introducción al pensamiento picaresco, Salamanca 1972.

17 "La vida de Lázaro es de un anticlericalismo desbocado, agresivo y total; se extiende a todo el clero sin excepción, ya sea regular o secular", en ibid., 41.

18 “Este elogio,.., del 'deshonrado',..., del vagabundo,.., es lo que de veras distingue a la materia picaresca fundamentalmente española de las obras que los historiadores de las literaturas francesa e inglesa han clasificado en sus respectivos dominios.", Marcel Bataillon, Pícaros y picaresca, Madrid 1969, 205-206.

19 La pícara Justina [Medina del Campo 1605], ed. Barcelona s.f., 56.

20 "Caridad con... los ricos", El Padre Padilla, 25.8.1887. Hasta 1891 era claro que en Chile existía esa básica diferenciación social y económica: "En Chile no hay más clases sociales que la de los pobres y de los ricos, los ilustrados y los ignorantes, los futres y los rotos.", Fanor Velasco, $L a$ revolución de 1891. Memorias, Santiago 1925, 363. 
El lenguaje de la Picaresca española habla desde la indecencia, la agudeza y el ingenio, pasó a América a raudales. La lengua 'oficial', del Estado y de la Iglesia, siempre se molestó frente a esta habla desordenada y desbordada. Los catecismos, o formularios del buen creer y del buen decir coloniales, fueron muchas veces intentos para sustituir las "obscenísimas cantinelas y torpísimos corridos" que entonó la plebe hispanoamericana, por ejemplo, en el siglo XVIII ${ }^{21}$.

La tradición de la Picaresca española -y de la cual depende sin duda Allendeentroncó todavía más atrás con una sensibilidad ibérica característica, que tuvo que ver, y no poco, con la influencia del Islam. Uno puede pensar en Juan Ruiz y el Libro de Buen Amor, expresión de mudejarismo popular del siglo XIV. Allí se realiza una crítica importante al clero, al rol del dinero y una exaltación del amor, especialmente erótico, de inspiración musulmana, en un tiempo de transición hacia el capitalismo, que permite comprender también el espíritu de las composiciones de Allende 22 . Un tema recurrente en el pensamiento morisco español fue acusar al clero de estar involucrado con la riqueza y el dinero, tema satírico que abundó -por otra parte- en la literatura de los siglos XVI y XVII ${ }^{23}$. En el siglo XV el poeta satírico y renegado o muladí Abd Allah al-Taryuman desplegó una serie de historietas anticlericales en España ${ }^{24}$.

La picaresca y satírica comicidad de Juan Rafael Allende tuvo, de consiguiente, una enorme y compleja tradición espiritual y literaria propia de España, eslabón entre la Cristiandad y el Islam, y expandida por toda Iberoamérica. Era un habla popular que venía forjándose por siglos y siglos, y que hizo del mundo ibérico -y aun más mestizo iberoindígena- un mundo sumamente particular, y especialmente refractario a la mitología de la modernidad ${ }^{25}$. En el caso de Chile, esto fue mucho más contundente debido a la importancia del componente morisco de los ibéricos llegados durante los siglos XVI y XVII. Este componente contribuyó a la existencia en el país de un modo de vida pendenciero, díscolo e insubordinado. La jocosa figura de Pedro Urdemales, festejada durante generaciones por el pueblo chileno, reveló el prestigio de un personaje de 'frontera' burlesco ante el poder establecido de curas y patrones ${ }^{26}$. El mismo Juan Rafael Allende publicó precisamente un periódico con el título de Pedro Urdemales, al agudizarse el conflicto de Balmaceda con la aristocracia, en 1890 y $1891^{27}$.

21 Humberto Triana, Léxico documentado para la historia del negro en América, siglos XV-XIX, Santafé de Bogotá 1997, 405, 418. Los poetas populares chilenos en la época colonial, por su parte, improvisaron en "versos ligeros, picarescos e ingeniosos", Matías Rafide, Literatura chilena (apuntes elementales), Santiago 1955, 13.

22 Julio Rodríguez-Puértolas, Juan Ruiz Arcipreste de Hita, Madrid 1978.

23 Louis Cardaillac, Moriscos y cristianos. Un enfrentamiento polémico 1492-1640, México 1979, 322.

24 José García Mercadal, Antología de humoristas españoles del siglo I al XX, Madrid 1957, 54.

25 "Los iberos [han sido un] pueblo esencialmente refractario al capitalismo e inaccesible a la atracción que el oro ejerce sobre casi todos los pueblos", Werner Sombart, El burgués, Madrid 1972, 218.

26 Luis Thayer Ojeda, Elementos étnicos que han intervenido en la población de Chile, Santiago 1919, 62-63.

27 En su primer número, dijo Juan Rafael Allende como Pedro Urdemales: “[Los] banqueros, los salitreros, los bragueteros de la aristocracia chilena no obedecen a los razonamientos del honor y del patriotismo, sino a los azotes y a los palos del verdugo... [Como] el caudillo moro exclamaré: 'Sangre! Exterminio! Fuego! / Sangre! Lebreles! Si sus dioses hallo, / Y hasta su templo llego, / Venid a verlos 


\section{Un habla burlesca y desenfadada}

Juan Rafael Allende hizo una literatura que los representantes del Occidente burgués y cristiano en el país solo pudieron calificar de "papeluchos de burdel, por demás obscenos, calumniosos e infames" 28 . Sus escritos eran dañosos "a la fe y a la pureza de las costumbres"29. Era la "prensa impía e inmoral", que debía ser aplacada incluso con peticiones e intercesiones públicas a la Virgen del Rosario, como se hicieron de hecho el año $1886^{30}$. Allende era el "redactor del periódico más sucio y más miserablemente canalla de Chile"31. Lo que hacía Allende era recoger y recrear el habla festiva y bufonesca del pueblo chileno. Juan Rafael Allende rebuscó profusamente el idioma satírico popular de calles, plazas y arrabales. Gracias a él conservamos los nombres cómicos de las trabajadoras del Ferrocarril Urbano de Santiago, las conocidas entonces como "conductoras". Estas eran la "Chancho Relleno", la "Pan con Queso", la "Escabeche", la "Lunarienta", la "Cara de Cascajo", entre otras $^{32}$. Él mismo fue un formidable e inagotable creador de apodos: "Hermójenes Peras de Engarce", para Hermógenes Pérez de Arce 33 . "Cucho Yeguas", para Agustín Edwards ${ }^{34}$. "Barros Culo", para Ramón Barros Luco. "Inclemente Fabriciano" o "Clemente Fiebres", para Clemente Fabres. "Melchor Garrocha", para Melchor Concha $^{35}$. "Manuel Vaquedando", para el general Manuel Baquedano ${ }^{36}$. "Diego Palotes", para Diego Barros Arana ${ }^{37}$. "Pedro No Las Comprende", para el poeta cortesano Pedro Nolasco Préndez ${ }^{38}$. "Bocas de Mastines", Carlos o Joaquín Walker Martínez 39. "Zorro Babel" Rodriguez, para Zorobabel Rodriguez ${ }^{40}$. Y "Federico Champaña", para el presidente de la República Federico Errázuriz Echaurren ${ }^{41}$. El templo santiaguino de la Gratitud Nacional fue llamado por Allende el templo de la "Ingratitud Clerical" 42 . Y a los parlamentarios era mejor llamarlos "parlamentirosos" 43.

luego / Atados por los pies a mi caballo,", Pedro Urdemales, 22.10.1890. El historiador racista Francisco A. Encina comprendió -y temió- el enfrentamiento social y cultural entre la élite castellanovasca y lo que denominó la influencia andaluza o "el elemento meridional, mucho más numeroso e intelectualmente más ágil" en Chile. El elemento "meridional", añadió, estaba predispuesto contra la élite "por las oposiciones de temperamento, caracteres y concepción de la vida", Francisco A. Encina, La presidencia de Balmaceda, Santiago 1952, II, 38, 356.

28 El Estandarte Católico, Santiago, 15.10.1886.

29 Idem., Santiago, 18.10.1886. Este periódico publicitaba por esos días el edicto del vicario capitular de Santiago Joaquín Larraín Gandarillas prohibiendo la lectura de las obras 'pecaminosas' de Juan Rafael Allende.

30 El Estandarte Católico, Santiago, 21.10.1886.

31 Idem., Santiago, 1.5.1888.

32 El Padre Padilla, 30.10.1888, 1.11.1888.

33 Idem., 27.4.1889.

34 Don Cristóbal, 23.8.1890.

35 Pedro Urdemales, 3.12.1890.

36 Idem., 6.12.1890.

37 Idem., 10.12.1890.

38 Idem., 24.1.1891.

39 El Padre Padilla, 5.5.1887.

40 Poncio Pilatos, 21.3.1899.

41 Idem., 4.3.1899.

42 El Padre Padilla, 23.8.1887.

43 Idem., 25.6.1889. 
Las alusiones picarescas, de connotaciones sexuales, no escasearon en el habla de Allende. Refiriéndose a los 'cuernos' del famosísimo historiador y político Diego Barros Arana, escribió el mordaz autor un diálogo entre el "Diego Palotes" y un Buey:

"El Buey: Yo soy un buey que conforme

Me paso con mis eternos

Males viejos y modernos,

Con el peso más que enorme

De mis años y mis cuernos.

Don Diego: Manso buey, echa esa pata,

Pues sábete, aquí entre nos,

Que a mí también ¡vive Dios!

Un sentimiento me mata...

ii $i$ Nos parecemos los dos!!!"44.

A la ilustre matrona, católica y millonaria doña Juana Ross de Edwards, verdadera reina Victoria local, le llegó también la bufonesca alusión: "La Juana Ross de Edwards ha pedido privilegio exclusivo para vender entre las 'vírgenes' de manto, pollera y alfombrilla, un 'Consolador Eucarístico' de su invención.- Casanova y Donoso [arzobispo de Santiago y gobernador eclesiástico de Valparaíso, respectivamente] han protestado" 45 .

Esta forma de hablar ciertamente no tuvo absolutamente nada que ver con la poesía oficial, seria, aburrida, de salón, que cultivaba la elite por entonces en el país. Como dijo alguien -que seguramente no quiso conocer a Allende- en 1885: "Si los poetas no hacen allí [en Chile] un papel tan considerable como el de los banqueros y los grandes propietarios, no por eso se les desdeña... Se les halla sentados en las curules de las Cámaras, en los bufetes de la prensa, en las cátedras de la Universidad y en los salones de la diplomacia;..."46.

Efectivamente había ciertos escritores de elite que compartían sus inquietudes poéticas con sus ocupaciones profesionales, pero que no expresaban la sal y la pimienta del habla popular de Chile. Muchos hablaron contra la risa: "Te ríes! Oh! mujer desventurada, / Tu risa me da lástima, es la risa / De pobre loca..." 47 . Otros elogiaron la risa, pero diciéndolo en francés, como Jorge Huneeus Gana ${ }^{48}$. Juan Rafael Allende se rió a mandíbula batiente de estos seudoescritores de la elite como Guillermo Puelma Tupper. En cierta oportunidad lo 'columpió' a propósito

\footnotetext{
44 “Don Diego de la noche...”, en Pedro Urdemales, 17.1.1891.

45 Pedro Urdemales, 3.3.1891.

46 Prólogo de José M. Samper, a Ambrosio Montt y Montt, Veladas líricas, Montevideo 1885, XII.

47 Ambrosio Montt y Montt, Veladas líricas, Montevideo 1885, 181.

48 “Quand tu ris, sur ta bouche / l'amour s' épanouit; / et soudain, le farouche /.... Ah! Riez, riez ma belle, / riez, riez toujours!”, Jorge Huneeus Gana, Plumadas, Santiago 1887, 190.
} 
del verso de este que decía: “¿Por qué en un instante / Lo chico se agranda?" 49. También Allende se burló festivamente del escritor de elite Alfredo Irarrázaval Zañartu, intelectual al servicio de Agustín Edwards y contrario al presidente de la República José Manuel Balmaceda. Irarrázaval, casado con Ester Mac-Clure Ossandón, era cuñado del famoso director de La Epoca, Eduardo Mac-Clure Ossandón. En 1888 Allende le dedicó unos versos que decían: "Señorito / Don Alfredo, / En mi traste / Mete un dedo /..."50. O este otro, motivado por los ataques del intelectual de elite contra el Partido Democrático:

“¿Qué piensas, futrecillo

De mala facha,

Al herir con tus dardos

La Democracia?"51.

Eduardo Mac-Clure Ossandón, el poderoso oligarca que inspiró la figura del "rey burgués" en el Azul de Rubén Darío, fue también víctima de la sátira de Allende. Con alusiones a su cuñado Agustín Edwards Ross, dijo de él en 1890:

"Calla, pelos en la sopa,

Diarrea de disparates;

Escoba de las letrinas

De tu cuñado el banquero, /... /

Tabardillo del Congreso,

Concierto de verduleras;

De Cuaresma 'cucurucho';

Y de agua bendita pila;

Y serrucho que se afila;

Y microbio de don Cucho: /.../"52.

49 El Padre Padilla, 18.4.1889. Otras referencias de Allende contra Puelma Tupper, Don Cristóbal, 7.6.1890. Guillermo Puelma Tupper fue un típico político de la oligarquía clasista de fines del siglo XIX. Para él, todos los "caballeros" estaban contra el presidente Balmaceda, a quien solo apoyaban los infelices, o los empleados públicos, Luis Orrego Luco, Memorias del tiempo viejo, Santiago 1984, 214. Puelma Tupper fue un dirigente masón, fundador de la Respetable Logia Verdad $\mathrm{N}^{\mathrm{o}} 10$, cfr. Revista Masónica de Chile XXIX, 3-8, 1952, 163.

50 A Don Alfredo, El Padre Padilla, 10.7.1888. Otras críticas de Allende: "Don Alfredo Irarrázaval Zañartu, queriendo adular a su patrón don Agustín Edwards, publica en La Libertad Electoral..." etc. O "Don Alfredo... solo ha conseguido hacer unos alejandrinos que hubiera tenido vergüenza de firmar Bernardino Guajardo.”, Don Cristóbal, 1.7.1890. La composición “A Don José Manuel Balmaceda" de Alfredo Irarrázaval Zañartu, en La Libertad Electoral, 16.7.1890. Sobre Irarrázaval, Alone, Diario íntimo 1917-1947, Santiago 2001, 77.

51 A Alfredo Irarrázaval Z., El Padre Padilla, 17.7.1888.

52 A Eduardo Mac-Clure, alias Tripulina, Don Cristóbal, 6.9.1890. Sobre Mac-Clure y su representación en Rubén Darío, José Antonio Portuondo, "Literatura y sociedad en Hispanoamérica", en Leopoldo Zea comp., Fuentes de la cultura latinoamericana. II, México 1993, 524. Mac-Clure firmó la deposición del presidente Balmaceda en 1891. Y bajo la presidencia de Federico Errázuriz Echaurren, entre 1896 y 1901, su poder fue aun más incontrastable. En 1899 Allende lo acusó de su cercanía corrupta con el presidente de la República: "Don Eduardo es el proveedor de carne fresca de $\mathrm{Su}$ Majestad don Federico el lascivo.”, Poncio Pilatos, 9.3.1899. 
En otra oportunidad se burló del redactor del periódico El Mercurio Augusto Orrego Luco: "Augusto Orrego Luco. / Alienista y escritor / Que ha comprado buena casa / Lo que prueba que el patrón / Paga bien y en buena plata"53. Muchos otros intelectuales de elite fueron motivo de la pluma satírica de Allende. Así, el sobrino de Diego Barros Arana, Luis Barros Borgoño (1858-1943), fundador del Ateneo de Santiago en 1888, catedrático de Historia del Instituto Nacional, y candidato a la presidencia de la República en 1920, recibió estos dardos por su filiación conservadora en 1891:

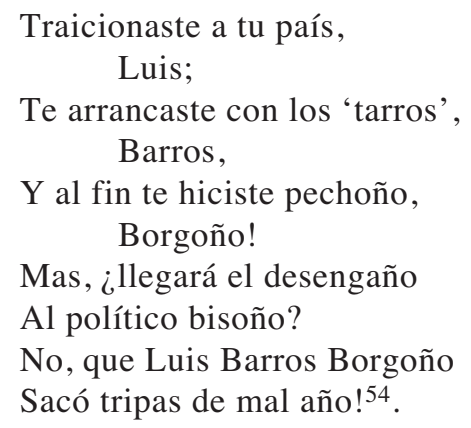

También Allende escribió un sonetillo burlesco contra el famoso intelectual Eduardo de la Barra, autor reconocido por ser "un maestro incansable, un miembro correspondiente de la Real Academia Española poseído de la manía de versificar" 55 .

\section{La sátira a la burguesía y su asalto a la política chilena}

Decimos que un tema de la Picaresca y de la literatura española medieval más connotada -como el Libro de Buen Amor-desarrolló en abundancia el motivo de la crítica a los ricos, a la clase burguesa, vistos con desprecio y olímpico desdén. Werner Sombart apuntando a una de las cumbres de la literatura de España señaló que Don Quijote era "el tipo menos capitalista de la historia mundial" 56 . Los ricos de Chile siempre quisieron 'ennoblecerse', ya desde el siglo XVIII, siendo como eran, sobre todo, unos tipos perfectamente burgueses. Juan Rafael Allende los desenmascaró en su verso Los nobles de Chile de 1891:

53 "Retratos parlamentarios", El Padre Padilla, 12.7.1888.

54 "Retrato al pastel", Pedro Urdemales, 7.3.1891. Barros Borgoño fundó el Ateneo de Santiago junto a otros intelectuales de la época satirizados por Allende como Jorge Huneeus Gana, cfr. Ateneo de Santiago. Por el conocimiento de la ciencia y la literatura (1888-1996), Santiago 1997, 36.

55 A Eduardo de la Barra. Sonetillo, Poncio Pilatos, 8.4.1899. De la Barra fue un eminente dirigente de la Masonería. Fue "primer Soberano Gran Comendador del Supremo Consejo fundado en 1899", cfr. Revista Masónica de Chile, XXIX, 3-8, 1952, 161. La opinión transcrita sobre su obra literaria, Fernando Alegría, La poesía chilena. Orígenes y desarrollo del siglo XVI al XIX, Santiago 1954, 274.

56 Werner Sombart, El burgués, Madrid 1972, 244. 
“-¿Hay nobleza en Chile? -Sí,

Una muy fina, muy doble,

Una nobleza más noble

Que el ponche y el chacolí.

Es nobleza que joroba

A la sociedad entera,

Una nobleza usurera

Que estruja al pueblo y lo roba.

Nobleza que por la plata

Hasta con Dios entra en riña

Y que, no sólo rapiña,

Sino que rapiña y mata.

Nobleza conservadora,

Que finje al Dios verdadero

Adorar, y que al Dinero

Tan sólo en su vida adora.

Nobleza sin pergaminos,

Que entre sus hijos mejores

Cuenta a falsificadores,

A ladrones y asesinos.

$\cdots$

Nobleza que ve sin calma

Que virtud tal vez le sobre

A un pobre, porque ese pobre

No tiene podrida el alma.

Nobleza siútica, infame,

Que a un hombre honrado desprecia,

$\mathrm{Y}$ a un rico ladrón ¡la necia!

Humilde, los pies le lame ${ }^{57}$.

En un texto mucho más explícito de referencias personales, Juan Rafael Allende se burló simultáneamente de cinco burgueses chilenos: Eduardo Matte, Manuel José Irarrázaval (marqués de la Pica), Agustín Edwards, Julio Zegers y Federico Varela. Todos ellos se identificaron en la lucha política -y aun militar- contra el presidente de la República José Manuel Balmaceda. Para Allende, la condición de burgueses fue la que le abrió a estos cinco hombres públicos el acceso a los privilegios políticos y culturales de la elite local. Sin su condición de audaces y exitosos burgueses habrían sido solo integrantes de una mediana e ignorante clase

57 "Los nobles de Chile", en El Recluta, 23.4.1891. 
media, ajenos del todo a los resplandores concedidos por los espacios de la aristocracia gobernante del siglo XIX. Su crítica al dinero entronca con la que hiciera Quevedo en España en el siglo XVII: “¿Quién hace al tuerto galán / y prudente al sin consejo? / ¿Quién al avariento viejo / le sirve de río Jordán? / ¿Quién hace de piedras pan, / sin ser el Dios verdadero? / El dinero" 58 . El verso de Allende se titula Si no fueran millonarios... y es de 1890:

"Si Eduardo Matte no hubiera

Heredado la fortuna

Que lo hace noble de cuna,

Del saber una lumbrera,

¿Qué sería hoy, ¡Dios mío!?

En vez de andar entre gente,

Fuera un pobre dependiente

De algún pobre montepío.

Hoy visita los salones

De la altiva aristocracia,

Y es sabio, y tiene hasta gracia...

Sí, la que dan los millones.

Y, si el marqués de la Pica

Se quedara sin un cobre,

Y si fuera oscuro y pobre

Dependiente de botica,

¿Estuviera en el Senado?

$\mathrm{O}$ estuviera arreando bueyes,

En vez de dictarnos leyes

Como egregio magistrado?

Tal vez capataz de peones

En un oscuro rincón;

Pero en un sabio Solón

Lo han trocado los millones!

¿Y Cucho Edwards el banquero?

Se llama hoy 'don' Agustín;

Sin embargo, el borrachín

Es redondo como un cero.

A no ser rico, licor

Despachara u otra cosa

En la popular, famosa

Damajuana Tricolor.

Pero hoy en las discusiones

Toma parte en el Congreso,

58 Rosa Albor ant., Poesía satírica y burlesca del Siglo de Oro, Madrid 1999, 43-44. 
¡Y no se ríen de este 'leso'

Porque es dueño de millones.

¿Y Julio, rey del salitre?

Si no fuera millonario,

¿Qué sería? Un perdulario,

Un raterillo, un belitre.

Con el moño medio gacho

Andaría de seguro

Pidiendo un 'pancito duro'

Como miserable guacho.

Pero hoy entre los ladrones

De alto rango es un tertulio,

Porque ha sabido don Julio

Robarse muchos millones.

¿Y Federico Varela?

¿Sería ‘don' Federico,

Cuando nunca el muy borrico

Fue ni por broma a la escuela?

Y hoy hasta le dan el nombre

De Mentor o de Mecenas

De artes y letras chilenas,

¡Y hasta pasa por ser 'hombre'!

Entre torpes maricones

A un burdel viviera anexo,

Si no le cambiara el sexo

El poder de los millones!" 59.

La crítica de Allende contra la burguesía, representada sobre todo en los Edwards y los Matte, ya se manifestó airada en 1886: "Verdaderamente que, si el pueblo de Chile tuviera un poquito de más hígados y un poquito de más vista, hoy levantaría horcas en las plazas de Valparaíso y de Santiago, para colgar a esos explotadores del pueblo que se llaman Edwards, Matte y demás!... Abre los ojos, pueblo! Abre los ojos y ve quiénes te explotan y te roban!"60. Este lenguaje clasista se volvió explosivamente real en la prensa oficial del presidente Balmaceda en 1891: "Las personas de Matte, Edwards y Ross, deben ser juzgadas con arreglo a las leyes, y sus feas y repugnantes personas colgadas en medio de la calle de Huérfanos..."61.

59 "Si no fueran millonarios...", en Pedro Urdemales, 19.11.1890.

60 "Estrategia infame", en El Padre Padilla, 10.4.1886.

61 "Judíos y traidores", en La Nación, Santiago, 12.6.1891. "La revolución lleva en sus venas sangre de oro, y la raza judaica y usurera de Chile, la que fue monopolizadora de la fortuna en menoscabo del bienestar del pobre y del honrado, le prestó para nacer el calor de su propia existencia.", La Nación, Santiago, 24.7.1891. 
Uno de los burgueses más caracterizados por la pluma de Juan Rafael Allende fue el empresario Agustín Edwards Ross (1852-1897), presidente del Banco Edwards, presidente de la Compañía Chilena de Seguros, propietario del periódico El Mercurio desde 1880, y presidente de la Compañía de Salitres y Ferrocarril de Antofagasta en 1881. Se caracterizó por ser uno de los financistas de la Guerra del Pacífico y el principal promotor y financista de la Guerra Civil de 1891. Fue asimismo parlamentario, ministro de Estado, y miembro del Consejo de Estado. Tenía un "pronunciado aspecto británico"62. De él se dijo en 1884 que no solicitaba "los encomios del populacho"63. A su muerte, en 1897, la prensa burguesa y 'seria' lo destacó como uno de los ciudadanos más distinguidos y ejemplares del país. La prensa católica lo elevó por los cielos: "Favorecido por Dios con la fortuna más colosal de Chile, ni dio oído a las sugestiones de la soberbia, ni se dejó desvanecer por la lisonja. No heló su corazón al egoísmo, ni lo petrificó la avaricia... Lega, al morir, una crecida suma para la edificación de un templo" 64 . El Ferrocarril no pudo olvidar su participación en la Guerra Civil de 1891: "Era el señor Edwards uno de los hijos más amantes de esta querida tierra,... Su levantada y noble actitud en la crisis nacional de 1891 quedará como una brillante enseñanza y como el más abnegado ejemplo de civismo legado a los sostenedores de las libres instituciones en nuestro país" ${ }^{65}$. Y El Mercurio, de su propiedad, no pudo, naturalmente, quedarse atrás. El dueño del periódico era "un corazón bien puesto,... una alma abierta a las generosas expansiones del patriotismo,... una alma siempre abierta a los más generosos sentimientos de la justicia, de patriotismo y de amor a la humanidad". Era el "estadista que ha prestado a su patria más de veinte años de servicios en importantes puestos de honor y de responsabilidad"66.

Juan Rafael Allende con su mirada satírica y picaresca no reconoció los merecimientos burgueses de Agustín Edwards, sino que prefirió colocar sobre el papel las suspicacias del pueblo frente a un personaje que tenía tanta figuración pública como interés por sus negocios privados. En el tercer tomo de sus Poesías populares, publicado en 1881, Juan Rafael Allende, bajo el seudónimo de "El Pequén", escribió esta "Dedicatoria al Sr. Dn. Agustín Edwards":

"Señor don Agustín Edwards:

Mi atrevimiento perdone,

Mi temeridad disculpe,

$\mathrm{Si}$, poeta oscuro y pobre,

Con el respeto profundo

Que merecen los millones,

Le dedico este ramito

De humildes, campestres flores.

De mi libro en la portada

\footnotetext{
62 Luis Orrego Luco, Memorias del tiempo viejo, Santiago 1984, 184.

63 Apuntes biográficos del señor don Agustín Edwards Ross, Valparaíso 1884, 17.

64 El Porvenir, 3.11.1897.

65 El Ferrocarril, 3.11.1897.

66 El Mercurio, 1.11.1897.
} 
Estampar quería un nombre Que en oro puro trocara Lo que es vil y sucio cobre, Como lo hiciera Paraff En otros tiempos mejores; Y no hallando otro mas grande, Y no hallando mas noble Que el suyo, permita usted Que aquí su nombre coloque. Usted, que con mano larga Parte de sus bienes pone Al servicio del Gobierno, Que a los huérfanos socorre, Que costea instrumentales, Que arma y viste batallones, Que por servir a la patria Se desvela noche a noche, Merece eso y mucho mas... Aunque no faltan bribones Envidiosos, malas lenguas, Que dicen a grandes voces Que si usted hace limosnas Es porque se le perdone Tener el cambio tan bajo, Gracias a que mandó a Londres Unos veinte milloncejos Para hacer sus emisiones; Y agregan los deslenguados Tambien que si usted socorre A los huérfanos y viudas De nuestros bravos, es porque... En fin... porque usted pretende Que nuestros lejisladores No graven mas el salitre Con nuevas contribuciones, Aunque ya los congresales Le han dado el último golpe. $\mathrm{Y}$ aseguran todavía Esas lenguas de escorpiones... Pero no quiero seguir Apuntando aquí tan torpes Calumnias, pues casi, casi Sintiendo estoy tentaciones De creer lo que se dice... 
En fin... mejor es que borre De la frente de este libro Ese prestijioso nombre, Porque los remordimientos Me están royendo feroces La conciencia... y no querría, Aunque soy tan roto y pobre, Que dijeran que dedico Mis humildes producciones A los que sangran al pueblo $\mathrm{Y}$ en su cuello un dogal ponen Quiero ser independiente;

No quiero que me abochornen Llamándome adulador De los por el oro nobles! No soy cantor de los ricos! Soy el cantor de los pobres! Quiero al son de mi vihuela Entonar gratas canciones Celebrando a nuestros héroes Que combaten en el Norte $Y$ que mueren bendiciendo De la patria el santo nombre; Quiero cantar al Amor, A las chicas de buen porte, De ojitos de querubines, De encarnaditos colores, De boquitas que dan besos Dulces como huevo molle; Quiero reir de los tontos Que, porque tienen millones, Piensan que todo lo tienen.

Hasta creerse grandes hombres; Quiero ensalzar la virtud De sencillos corazones, Que nunca se puso a venta $\mathrm{Ni}$ hay dinero que la compre. En fin... no canto a los ricos! Soy el cantor de los pobres!"67.

El autor satírico no quiso, pues, comprometer su nombre con el de un burgués del cual se maldecían tantas maledicencias. Prefirió, al fin, apartarse de ese terreno

67 "Dedicatoria al Sr. Dn. Agustín Edwards”, El Pequén, Poesías populares, Santiago 1881, III, 3-6. 
y acordarse mejor del amor, de las mujeres hermosas, y de los preclaros intereses de los pobres. En el mismo volumen de poesías de 1881, Allende volvió a dudar del patriotismo del empresario, solo transparente en función de sus intereses particulares. Se trató del verso "Miserias de un millonario":
“¡Cómo! ¿Tan pobre está Cucho,
Cucho está tan arruinado,
Que no pueda ipobrecito!
Costear una banda al Blanco?
¿Será cierto que está pobre?
No, no! Esa, lector amado,
No es la madre del cordero,
Sino ésta que te señalo:
Cuchito no afloja ya
Porque está hecho el mismo diablo
Con la retasa al salitre
Que en el Congreso aprobaron.
Hoy no puede a dos carrillos
Cuchito seguir mamando;
De ahí proviene su enojo,
De ahí que se haya taimado.
¡Mezquindades de un banquero!
¡Miserias de un millonario!"68.

El año 1885 Allende le dedicó otra composición satírica titulada Nuestros millonarios. Agustín Edwards:

Cuando pienso en el tal nene,

Que tan encumbrado está,

Esta pregunta nos viene:

¿Por qué muelas Dios le da

Al que quijadas no tiene?

Reflexionando un minuto,

En limpio vengo a sacar

De mi reflexión el fruto

Como Cucho, no he de hallar

Otro más rico y más... bruto.

Sus bolseros se hacen bocas

Pregonando sus larguezas,

Que son pocas y muy pocas,

Pues Agustín sus riquezas

Las gasta a tontas y a locas.

68 "Miserias de un millonario", El Pequén, Poesías populares, Santiago 1881, III, 54-55. 
Aunque los vientos se bebe

Por subir en quinto y tercio, A nada bueno se atreve:

Nada le debe el comercio,

Nada la industria le debe.

Como yo todo lo escucho

Desde mi oculto vivac,

Solo oigo decir de Cucho:

'La importación del coñac

¡Esa, sí, le debe mucho!’

No le falta ni una pata

Para ser bestia a este Creso

Que hacer de persona trata;

Pues yo lo llamo por eso

Burro cargado con plata ${ }^{69}$.

A comienzos de 1886 Allende acusó a Edwards, junto a otros burgueses, de impedir un impuesto de exportación al salitre: "Los infames opositores al Gobierno, los judíos Matte, Concha y Toro, Edwards, y demás, han hecho la obstrucción impidiendo que se cobren contribuciones, con el objeto infame y criminal de robar al país entero!! Sepa el país que estos judíos agiotistas embarcan en este momento todos sus salitres, sin pagar contribución. De esta manera pueden ganar millones con el sudor del pueblo y robándole al pueblo lo que al Fisco roban no pagando esas contribuciones. Después de esto bajarán el cambio y así se acabarán de llenar. Sepa el pueblo que entre los gobiernistas no hay salitreros"70.

En un cierto momento, pero al parecer de modo circunstancial, el año 1887, Allende elogió a Edwards, por favorecer la industria nacional ${ }^{71}$. Mas ya al año siguiente lo atacó por su excesivo poder económico local, junto a Pedro Montt. Edwards y Montt presidían la "araña monttvarista”, con intereses en bancos, ferrocarriles urbanos y de vapor, salitreras y periódicos. La crítica se extendió también al presidente Balmaceda por apoyar este poder:

"Su tela ya empezó

A tejer con el auxilio

De este Gobierno traidor,

Que entregarnos maniatados

Pretende a un Edwards y a un Montt,

Tipos los más despreciables

Que vientre humano engendró"72.

\footnotetext{
69 "Nuestros millonarios. Agustín Edwards", El Padre Padilla, 31.12.1885.

70 "Última hora", El Padre Padilla, 7.1.1886.

71 “AAdelante!”, El Padre Padilla, 7.7.1887.

72 "La araña monttvarista", El Padre Padilla, 26.4.1888.
} 
En el clima de la Guerra Civil de 1891, Allende desarrolló, con mucho más espíritu crítico, la imagen del empresario como un burgués escaso de intereses nacionales o patrióticos en su lucha contra el gobierno de Balmaceda. Su propia fortuna la habría labrado su padre, Agustín Edwards Ossandón, mediante la adquisición indebida de mineral robado llamada "cangalla". De tal padre, el hijo debía continuar su herencia. Así lo planteó en su poesía titulada "Paralelos" de 1890:

“¡Miradlo! Bota el dinero

Que, según cuenta la crónica,

Acumuló 'cangallero'

De una manera muy tónica

Su papá, en pueblo minero.

¿No sabéis lo que es "cangalla"?

Comprar siempre un 'gordo robo'

Cual solo lo hace un canalla

Que engatusa como a un 'bobo'

Al ladrón que afloja o calla.

Era pobre como Adán;

Mas, 'cangallando' afianzó

Gran fortuna con afán;

Y de tal palo salió

La astilla, que es un patán.

Que de tal padre, tal hijo

Saliera, no hay que dudarlo,

Un sabio refrán lo dijo.

¿Quién se atreverá a negarlo

Si está tangible y tan fijo?

El pobre padre fue el rey

Del dinero, en pocos años.

$\mathrm{Y}$ ese hombre sin Dios ni ley

Con sus maldades y engaños

Formó 'cangallera' grey.

Robaba, de gran valor,

Ricas piedras el minero.

-Vale cien... -Doy diez.- Señor...

-Me vendes, o vas ligero

De aquí a la cárcel, y es peor. 
Con semejante amenaza

El pobre ladrón vendía.

¿Qué tal? La espléndida caza

De 'cangalla', día a día,

Daba esplendor a su casa.

Si el padre fue 'cangallero',

Ahora el hijo bota el jugo

De negocio tan rastrero,

Haciendo llevar el yugo

A tanto y gran caballero.

La fortuna que se forma

Por medios tan criminales,

Del malvado da la norma:

El que nació en los barriales

Nunca su instinto reforma.

Comparad! Fue 'cangallero'

El padre; el hijo en la usura

Se come hasta el chacanero.

Pueblo! Con la mano dura

Marcad al gran usurero!"73.

Durante la Guerra Civil de 1891 fue común acusar a Agustín Edwards de "cangallero"74. Allende también criticó a la madre del empresario, a doña Juana Ross viuda de Edwards, por el lujo burgués de tributar un homenaje a los héroes nacionales Arturo Prat e Ignacio Serrano con coronas encargadas a Europa ${ }^{75}$. El rol del empresario de origen británico en el financiamiento de la oposición política a Balmaceda, Allende lo caricaturizó mediante la adaptación de una popular canción habanera de la época a la que rebautizó como "La monttvarista":

"Si a la Moneda llega

Un monttvarista,

Trátalo como a un perro,

Porque es pancista.

Córtale bien las uñas,

$\mathrm{Y}$ a todas horas

73 Pepe Chiflón, "Paralelos", Don Cristóbal, 8.7.1890. Sobre el tema de la "cangalla", Daniel Palma, Historias de cangalleros. La sociedad minera y el robo en Atacama, 1830-1870, en Colectivo Oficios Varios, Arriba quemando el sol, Santiago 2004, 51-52.

74 Ver El Correo del Sur, 2.7.1891, citado en Fanor Velasco, La revolución de 1891. Memorias, Santiago 1925,478 .

75 El Padre Padilla, 22.5.1888. 
Corónalo de espinas

Bien punzadoras.

¡Ay! Cuchito, que sí!

¡Ay! Cuchito que nó!

Cuchito, ven conmigo

Adonde vivo yo.

Dicen que están muy tristes

Los mocetones

Porque ya don Cuchito

No da millones.

Les ha dicho: 'Ya plata

Darles no puedo;

Así es que, mientras tanto,

Chúpense el dedo'.

¡Ay! Cuchito, que sí!

¡Ay! Cuchito, que nó!

Cuchito, ven conmigo

Adonde vivo yo ${ }^{76}$.

Sabemos que el presidente de la República José Manuel Balmaceda llegó a intervenir el Banco Edwards, pues "lo acusó de ser una de las fuentes de financiamiento de la oposición"77. El cumpleaños del empresario no fue sino un motivo para expresar Allende su sátira, incluyendo alusiones a su crónica falta de salud. Edwards falleció a los 45 años de edad de tuberculosis:

"Gran banquero de enormes talegas,

Oye bien la entusiasta canción

Que las reinas de charcos y vegas

Te dedican con júbilo hoy [...].

Nadie, nadie alcanzó dicha tanta,

Nadie obtuvo un igual parabién;

Si hasta el sapo, Cuchito, te canta,

¿Ambicionas más gloria tener?

Yo te mando, feliz, por la posta,

Por consejos de un sabio doctor,

76 "La monttvarista. Habanera", Don Cristóbal, 2.8.1890. Se trataba de la habanera con la letra: "Si a tu ventana llega / una paloma / cuéntale tus amores / que es mi persona...", Manuel Peña Muñoz, La vida cotidiana en la época de Balmaceda, en Mapocho 30, 1991, 25-26.

77 Ricardo Nazer, Juan Ricardo Couyoumdjian, "Un patrimonio familiar: la fortuna de Agustín Edwards Ross y sus herederos, 1879-1905”, en Boletín de la Academia Chilena de la Historia $\mathrm{N}^{\circ} 111$, 2002, 345 . 
Una opiata de orines y bosta

Que te sane al instante el pulmón.

Y la patria, Agustín, cuya plata,

Has robado con bárbara sed,

Te regala una banda... de lata

Y en el... 'cuerpo' te da un puntapié! ${ }^{78}$.

Edwards, para el autor satírico, era un "burrito cargado con plata", obsecuente del todo con los líderes de la causa opositora del Congreso -los parlamentarios Waldo Silva o Pedro Montt- contra el presidente Balmaceda:

"¿Ves, lector, a ese noble jumento?

De británica raza es, lector;

De la usura y el agio, portento

De la guerra, servil 'gastador'.

Se le llama el burrito 'pagano',

Porque, a un gesto de Silva o de Montt

El tontito les abre la mano,

Aflojándoles medio millón [...]"79.

Juan Rafael Allende compuso un "Catecismo de la doctrina judía que enseñan los revolucionarios", con alusiones a Agustín Edwards. Al decir doctrina 'judía' debemos entender la alusión, en lenguaje ibérico y popular, a los ricos, adinerados y banqueros, tal como se venía diciendo en España desde el siglo XIV. Durante el reinado de Alfonso XI, en la primera mitad de dicho siglo, hubo motines populares antisemitas combatiendo a los judíos identificados con el capitalismo de la elite castellana ${ }^{80}$. Allende inventó el 'Padre Nuestro' de la nueva religión capitalista y su asalto al Estado chileno de fines del siglo XIX. Ahí encontramos alusiones a la sublevación de la Escuadra y al gobierno revolucionario del Congreso contra Balmaceda: "Agustín Edwards, padre nuestro, que estás en los cerros escondido, tontificado sea tu nombre; venga a nos tu reino; mientras nos des dinero, hágase tu voluntad en la tierra como en el mar. El pan nuestro de cada día nos cuesta un platal; perdónanos nuestras deudas, así como se las perdonaste a Orrego Luco, Isidoro Errázuriz, Pedro Nolasco Préndez, Aguirre Vargas, etc, etc, para que nosotros te perdonemos el que nos hayas metido en un pantano del que no podemos salir; no nos dejes caer en la tentación de seguirte acompañando; mas líbranos de los vales y fichas del Congreso flotante. Amén" 81 .

78 Moscardón de Milán, “A Agustín Edwards en su cumple-años. 28 de agosto de 1890”, Don Cristóbal, 30.8.1890. Las aficiones alcohólicas de Edwards fueron siempre un motivo de sátira para Allende: "Su cabeza es un corcho y su cuerpo un tonel. Es un mamífero que chupa alcohol de 45 grados. ¡Y no revienta!”, "Museo Parlamentario", El Padre Padilla, 13.6.1888.

79 "Un burrito cargado con plata", El Recluta, 23.6.1891.

80 Julio Rodríguez-Puértolas, Juan Ruiz Arcipreste de Hita, Madrid 1978, 145-146.

81 "Catecismo de la doctrina judía que enseñan los revolucionarios. El Padre Nuestro", El Recluta, 9.5.1891. 
Varios hombres públicos de la época fueron vistos en la connivencia o bajo la protección del banquero y dueño de El Mercurio. Así encontramos alusiones de Allende a la relación de Edwards con José Besa:

“[...] ¡Bodegonero traidor!

Hoy tan ufano, tan ancho,

Y ayer cabezas de chancho

Vendías que era un primor,

[...] Tú de Edwards vil lebrel,

Arranca y salva el cogote,

Que está listo el 'chafarote'

Que ha de tocarte el rabel!" 82 .

Mediante una parodia de un romance tradicional del folclore infantil chileno, Allende relacionó también a Edwards con quien sería años más tarde presidente de la República, Federico Errázuriz Echaurren:

“_AAdónde vas, Federico,

Con esa cara de juez?-

Y me respondió el tití,

$\mathrm{Su}$ furia sin contener:

-Yo me voy muy enojado

A los palacios del rey

De la Usura, a darle aviso

De que Balmaceda el cruel

De lo alto de la Moneda

Me ha arrojado a puntapiés,

[...]-Consuélate, Federico;

Cucho sabe pagar bien,

Y él te pagará las penas

Que ha sufrido tu altivez

Comprándote en el Congreso

Un asiento, que, a mi ver,

El sufragio popular

Te lo negará esta vez" 83 .

Otro político criticadísimo por Allende debido a sus relaciones con Agustín Edwards fue el miembro del Partido Radical y de la Masonería Enrique Mac-Iver (1845-1922). “[Don] Enrique Mac Iver, el político más sinvergüenza y venal que pisa tierra chilena... El último demócrata gana su vida con su trabajo honrado; pero Mac Iver, si bien de ruin origen y de canalla estirpe, e hijo de vagabundo ex-

82 “A Ño José Besa", Pedro Urdemales, 31.1.1891.

83 "Federico el guapo", Don Cristóbal, 11.10.1890. 


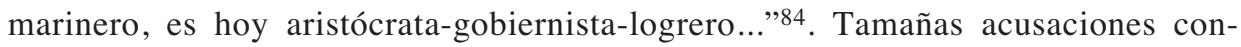
trastaron con la opinión apolínea que cultivó la elite acerca de dicho personaje. Por ejemplo, Julio Zegers, político contemporáneo, escribió del dirigente radical: "En ese político..., se ve al estudiante sobrio, que no ha usado de su juventud, que sólo ha leído y pensado... ignora las dilapidaciones de los afectos, de los deberes y de los dineros propios y ajenos" 85 .

Allende le dirigió la siguiente Carta política en 1890: "Mi querido Enrique: Cuando te veo ahora tan alto, y todo porque, pisoteando la bandera radical, te has hecho 'sangrador a firme' del oro de Cucho, sin acordarte que el Gobierno también te permitió 'estrujar' al Erario, se me subleva la envidia, y quisiera como tú también pisotear esa bandera radical que te sacó de lo desconocido. Quince años reconoces tú de vida pública. Es cierto. Pero en estos tres últimos te echaste a la espalda la vergüenza, y ya tienes en tus faltriqueras buenos miles de morlacos. Verdad que has 'discurseado' de lo lindo para realizar ese acopio de 'viles chauchas' que, no siendo tú tonto, las tienes de cuño inglés [...]. ¡Qué ganga, hombre, verte en sabroso consorcio con Besa y Montt, Edwards y los pechoños! [...] ¿Cómo ahora estás con tus enemigos de ayer, y con el angelito del 9 de enero, al partir de un confite? Ah! se me olvidaba: el poder del oro... Créeme: si estás repleto, no importa la caída; pero, si no sí; procura aprovechar el tiempo, que Cucho tiene que brocear su mina, y las labores no dejarán beneficio ni para un miserable 'pirquén' [...]"86.

El caso emblemático de un hombre público enriquecido por sus vinculaciones con la riqueza del salitre y que pasó del apoyo a la enemistad con el presidente Balmaceda fue Julio Zegers, el "principal abogado de North en Chile"87. Este era un político "en apariencia frío, tranquilo e inmutable" 88 . Para Allende era un "insaciable cocodrilo" 89 , que había que "cortarle las uñas cada veinticuatro horas" 90 . En un homenaje necrológico El Mercurio lo encumbró por los cielos: "Su labor en el Ejecutivo es tan espléndida y atinada como la que cumplió patrióticamente desde el cargo de legislador y está expuesta ante la historia como un cívico ejemplo de lo que puede y está obligado a hacer el chileno inteligente y amante de su tierra nativa... Venido al mundo en un colosal año para la historia chilena [nació en 1833], grande había de ser su figura. Vio la luz junto a la Carta Fundamental de Chile, que con previsor ojo nos dieron los republicanos talentos del 33, cimentando sobre inconmovible y próspera base a la patria... Sus mayores triunfos de foro los

84 "Un noble de arrabal", en El Padre Padilla, 25.10.1888.

85 Julio Zegers, Enrique Mac Iver, en Revista Chilena XIV, LIV, agosto 1922, 399.

86 "Carta política. Señor don Enrique Mac Iver. Santiago", en Don Cristóbal, 23.8.1890. Mac-Iver ha sido rememorado por sus admiradores como un "noble varón", un "insigne patricio", un "ciudadano integérrimo", un "verdadero estadista", cfr. Revista Masónica de Chile, XLI, 1-2, 1964, 5-7. Otras alusiones de Allende a Mac-Iver, cfr. Maximiliano Salinas, Juan Rafael Allende El Pequén y los rasgos carnavalescos de la literatura popular chilena del siglo XIX, en Historia 37, 2004, 219-220.

87 Leslie Bethell ed., Historia de América Latina. 10. América del Sur, c. 1870-1930, Barcelona 1992,172

88 Luis Orrego Luco, Memorias del tiempo viejo, Santiago 1984, 274.

89 "El salitre", El Padre Padilla, 4.4.1889.

90 Don Cristóbal, 3.7.1890. 
tiene como abogado de los negocios ingleses, los Ferrocarriles Salitreros, base de su fortuna privada y de su nombradía de hábil jurisconsulto"91.

Juan Rafael Allende se burló de sus posiciones a favor y en contra del presidente Balmaceda. Zegers pasó de la amistad con el Presidente a la más feroz oposición, junto a Agustín Edwards:

"Diz que don Julio Salitre,

Cuya alma en lo negro da

Las guachas al mismo buitre.

Desde hace algún tiempo está

Como que se va,

Como que se va,

Como que se queda.

¡Ay! el pobre no puede quizá

Olvidarse del señor Balmaceda!

Aunque el 'rico salitrero'

Bien pagarle a Julio pueda,

Como siempre fue logrero,

Está Julio en la vereda

Como que se queda,

Como que se queda,

Como que se va.

¡Ay! exclama, al mirar la Moneda:

¡Quién pudiese volar hacia allá!

En vano le dice Cucho:

'Acompáñame por hoy,

Pues te necesito mucho',

Pues Julio responde: 'Estoy

Como que me voy,

Como que me voy,

Como que me quedo.

¡Ay! Cuchito, las gracias te doy;

Pero aun resolverme no puedo'.

[...] ¡Julio y Máximo! ¡qué dos

Dignos hijos de Satán!

Tienen al oro por dios;

Por eso los dos están

Como que se van,

Como que se van,

Como que se quedan.

91 "Don Julio Zegers ha muerto", El Mercurio, Santiago, 1.5.1918. 
¡Ay! lectores, ustedes verán

Que ambos pronto en Palacio se hospedan!"92.

Un poema satírico dio cuenta de unos supuestos consejos de Julio Zegers a su hijo:

"Diz que don Julio Salitre,

Belitre según colijo,

Armó caballero a su hijo,

Que es, como el padre, un belitre.

Y, al armarlo caballero,

Le espetó una sabia arenga,

De la que quiero que tenga

Noticias el mundo entero:

[...] En tus futuros manejos,

Vas a seguir mis consejos,

Y ellos la dicha te den.

'Acaso nunca te arranque

El hambre ninguna queja,

Si, por más que sea vieja,

Sigues la doctrina yanque:

'Haz dinero honradamente;

Mas, si no puedes ipardiez!

Hacerlo con honradez,

Haz dinero... y sé prudente.

[...] Que sea tu sacerdocio

Siempre aumentar tu peculio...

¡Al Diablo la patria, Julio!

¡No hay más patria que el negocio!

El patriotismo es un mito;

El egoísmo una joya.

¿Hay negocio? ¡Que arda Troya

Y que Chile quede frito!

Estruja, como yo estrujo,

A ese pueblo soberano...

Después, tiéndele la mano

Más humilde que un cartujo.

[...] Y luego en público dí:

'Hijo del pueblo yo soy;

Todo al pueblo se lo doy:

92 “Don Julio Salitre", Don Cristóbal, 10.4.1890. 

Nada dejo para mí.'
Honrado corre la posta;
Haz dinero, y si ipardiez!
No lo haces con honradez,
Haz dinero... a toda costa!"93.

En medio de la Guerra Civil de 1891, Allende escribió El credo de los salitreros con abierta alusión a Julio Zegers: "Creo en mi padre, Mister North, creador de este conflicto y de esta guerra civil, y en Julio Zegers, que no es su único hijo, que fue concebido por obra de desgracia para el país, y nació de una que no fue la Virgen María, padeció bajo el poder de la miseria y el desprestigio, siendo, como político, crucificado, muerto y sepultado; pero, haciéndose salitrero, resucitó a los pocos días de entre los judíos; subió a la Moneda, y fue sentado entre las personas honradas y decentes, [...] creo en el salitre, en el yodo, en el nitrato, la comunión de los pícaros, el perdón de los robos de salitreras fiscales, la baja del cambio hasta cinco peniques y la ruina perdurable de Chile. Amén"94.

Allende criticó con picardía a una aristocracia que se encumbró en el poder político a expensas de sus relaciones familiares y terratenientes. Así le dedicó un poema a Ladislao Errázuriz Echaurren, hermano de Federico, quien llegaría a ser presidente de la República en 1896. Este poema es de 1890:

Tu hermano con su falacia,

De una dote roe el hueso;

Y tú ni aun para eso

Has sabido tener gracia.

¿En qué fundas, pues, tu petulancia?

Federico la funda en el fundo de su finado suegro.

¿Querrás fundarla tú en que eres hijo de tu padre?

[...] Oye, por más que te pique

Y si te pica, simplón,

¡Por Dios! que de ello me alegro:

No existe en la oposición

Otro hacendado Echeñique

Que quisiera ser tu suegro 95 .

Otros políticos aristocráticos y burgueses fueron escarnecidos por sus escasas convicciones democráticas, como fue el caso del 'marqués de la Pica' y líder conservador Manuel José Irarrázaval:

93 “Armándolo caballero", Don Cristóbal, 26.7.1890.

94 "El credo de los salitreros", El Recluta, 2.5.1891. Otros versos contra Julio Zegers, “A Julio Salitre...¿ZZegers?, en Don Cristóbal, 29.7.1890; y "Franqueza canta", en Don Cristóbal, 12.8.1890.

95 “A don Ladislao", en Don Cristóbal, 13.9.1890. 
Diz que el marqués de la Pica

No busca en la oposición

Fortuna grande ni chica,

Puesto que él se sacrifica

Por... don Carlos de Borbón.

Lo demás, grano de anís

Es para su señoría,

Que, desque estuvo en París,

Sueña con que su país

Se convierta en monarquía.

Y bien: ¿qué conservador

Que sea de buena ley,

No desea con ardor

Tener por rey y señor

Aunque sea a un peje-rey? ${ }^{96}$.

Otro capitalista satirizado por Allende fue Domingo Fernández Concha. A él le dedicó este verso de 1886:

En la caja arzobispal

Hace tiempo hizo una roncha

Este señor clerical;

Desde entonces es rico el tal

Domingo Fernández Concha.

Con razón este usurero

No escatima su tesoro

Cuando algo le pide el clero,

Puesto que todo su oro

Fue de la Iglesia primero.

Viendo que no era negocio

Vender por varas o al peso,

Se acordó del sacerdocio...

Buscó un socio, y halló al socio

En Valentín Valdivieso.

Improvisóse al momento

Prestamista el clerical;

96 "El sueño de un marqués", en Pedro Urdemales, 5.11.1890. 
Y diz que no le fue mal,

Pues, prestando al tres por ciento,

Hizo un gordo capital.

Ahora el baratillero,

Del Pontífice sectario,

De los pechoños banquero,

Es un señor millonario,

Es decir, un usurero.

Así, libre de quebrantos,

Posible es que se lo tome

Por un santo, como a tantos,

Porque los santos se come...

¡Lo que vale comer santos!97.

El mundo conservador católico fue parte fundamental de la oligarquía enriquecida por el salitre o la minería en general a fines del siglo XIX. De Joaquín Walker Martínez dijo que era de esos hombres "que se enriquecen robando con farsas de compañías mineras"98. En este sentido ni el arzobispo de Santiago -expresión máxima de los círculos políticos conservadores del momento- escapó de las bufonescas y picarescas críticas de Juan Rafael Allende. Este es un verso dedicado a monseñor Mariano Casanova, arzobispo de Santiago de Chile estrechamente vinculado a la familia Edwards. Vemos aquí una reproducción de la crítica a los clérigos enriquecidos, tal como la desarrolló en su tiempo el Lazarillo de Tormes en el siglo XVI. Es el caso del eclesiástico que mata de hambre al pobre, pero finge lo contrario:

Ayer por mi calle

Pasó el Arzobispo

Con varios adornos

Y dientes postizos.

Llevaban sus dedos

Hermosos anillos

Con muchos brillantes

Y muchos zafiros,

Sombrero y zapatos,

Eran nuevecitos;

Sus medias de seda,

Su capa, lo mismo,

En fin, que el traje era

Bastante bonito.

97 "Nuestros millonarios. Domingo Fernández Concha", El Padre Padilla, 16.1.1886.

98 El Padre Padilla , 10.7.1888. 
Mas, veamos ahora,

Ya que ello es preciso, $\mathrm{Si}$, como por fuera,

Por dentro es tan lindo.

Y yo que conozco

Que me sé al dedillo

La vida y milagros

De nuestro Arzobispo,

Puedo asegurarles,

Sin mentir ni pito,

Que el alma de este hombre

No es trigo muy limpio,

Que es muy orgulloso,

$\mathrm{Y}$ es muy vengativo,

Que en ninguna cosa

Representa a Cristo,

Pues éste era pobre

$\mathrm{Y}$ aquél es muy rico,

El uno vivía

Con gran sacrificio

Y el otro se pasa

En fiestas y mimos.

Por fin les advierto

Que lo que aquí he dicho

Le viene de molde

A un amigo mío

Que ha pensado siempre

Que nuestro Arzobispo

Tiene su carácter

Igual al vestido 99 .

La burguesía militarizada que asaltó el Estado en 1891 terminó gobernando Chile hasta el fin del siglo XIX. Allende designó a sus cabecillas Pedro Montt y Carlos Walker Martínez con estas palabras en 1899: “[La] Compañía de Opereta

99 "De Iriarte", Poncio Pilatos, 24.8.1893. El misal en que juró el almirante Jorge Montt como presidente de la República en 1891 fue regalado por la familia Edwards al arzobispo Mariano Casanova, y prestado por este para la ocasión. Casanova estaba en el centro del sistema ritual de la burguesía conservadora triunfante tras la Guerra Civil de 1891, cfr. El Chileno, 31.12.1891. Las burlas de Allende al clero fueron constantes. Al célebre orador sagrado Ramón Ángel Jara lo acusó abiertamente de homosexual: "Mas, los buenos sacerdotes / Aseguran, muy de veras, / Que sólo tu posaderas / Tienes para los... azotes!”, “A Ramón Ángel Jara”, El Recluta, 13.6.1891. El lujo burgués de Casanova siempre fue motivo del ataque satírico de Allende: "Señor don Mariano Casanova, ¿que no conoce usted a ningún huérfano, a ninguna viuda, a ningún desvalido padre de familia que necesiten del óbolo de la caridad, que usted encarga a Europa dos mitras que valen un dineral?", "La pobreza de nuestro Pastor", en El Padre Padilla, 18.4.1889. 
Bufa [...] funciona permanentemente en el Palacio de la Moneda Metálica [y sus] empresarios son los conocidos coreógrafos Montt, Walker y Cía., que con tan extraordinario éxito se estrenaron en esa capital el memorable 29 de agosto de $1891 " 100$.

\section{CONSIDERACIONES FINALES}

La obra satírica de Juan Rafael Allende es expresión de una tradición literaria humorística de vastísima trayectoria, que entronca con el espíritu de la Edad Media hispanoárabe, el Libro de Buen Amor y la Picaresca española. En Allende puede resonar incluso el espíritu de Ibn Quzmán y sus cómicos y regocijados zéjeles de la Córdoba medieval, que remontaron su más lejana procedencia a la poesía satírica y obscena de Bagdad ${ }^{101}$. Al comienzo de los Tiempos Modernos, esta tradición literaria pudo ser combatida hasta cierto punto -a través de los mecanismos del Estado absoluto- como un mundo de "proposiciones escandalosas, malsonantes, injuriosas y censurables", como se dijo en el siglo XVII ${ }^{102}$. Con el progresivo advenimiento de los valores democráticos y libertarios en el siglo XIX esta sátira de raigambre oral y popular encontró un lugar de mayor legitimidad expresiva a través de la literatura humorística y de crítica social y política. En este ambiente propicio, sobre todo en las dos últimas décadas del siglo -con el avance de un movimiento y una sociabilidad popular urbana, y la coyuntura final de la Guerra Civil de 1891-, Allende dio a conocer, como uno de los temas posibles de esta narrativa festiva y, hasta cierto punto, obscena, la crítica contra el espíritu económico burgués propio del siglo ${ }^{103}$.

¿Lo logró Allende? Como haya sido, su empeño fue poderosísimo. Su prensa circuló amplia y libremente -a pesar de las prohibiciones y reconvenciones, especialmente del clero- por todo el país, y especialmente entre las clases populares, cada vez más afectadas por la expansión burguesa del momento. Su obra inspiró y fomentó el espíritu satírico y de antiseriedad en la sociedad popular chilena de su tiempo hasta los albores del siglo XX. Desde esta popularidad, podemos comprender que la cultura de elite, ilustrada o burguesa -adiestrada en la universidad, la Iglesia, la escuela y los círculos de artes y letras-, fue mucho más pequeña y circunscrita que lo pudiera haberse imaginado. Mientras la elite buscaba inmortalizar en el bronce a sus héroes en los espacios públicos de Santiago -las estatuas

100 Poncio Pilatos, 4.3.1899. Sobre Walker y su pensamiento conservador, José Luis Romero, Pensamiento conservador 1815-1898, Caracas 1986, 214. Para Allende, el joven político burgués Arturo Alessandri Palma era solo un peón de Montt y Walker. Ellos lo nombran "primer seise de la capilla de cantores", Poncio Pilatos, 25.2.1899; 2.3.1899.

101 Emilio García Gómez, Poesía arábigoandaluza. Breve síntesis histórica, Madrid 1952, 81.

102 Cfr. Guillermo Lohmann Villena, Inquisidores, virreyes y disidentes. El Santo Oficio y la sátira política, Lima 1999.

103 Sobre la narrativa festiva y el ideal moderno burgués, Claudio Guillén, La expresión total: notas sobre literatura y obscenidad, en Carlos Castilla del Pino comp., La obscenidad, Madrid 1993, 41-98. 
rígidas a Portales, O’Higgins, Bello y Montt entre 1860 y 1904-, la prensa revoltosa de Allende, durante esos mismos años, alentó el espíritu popular contra una burguesía que podía ser cualquier cosa menos inmortal ${ }^{104}$.

Fecha de recepción: mayo de 2005.

Fecha de publicación: junio de 2006.

104 Sería importante estudiar el volumen total de la literatura satírica popular en las postrimerías del siglo XIX en Chile, y el impacto que pudo haber tenido en ella la influyente obra de Juan Rafael Allende. En 1894 y 1895 se destacaron, por lo menos, dos periódicos en este sentido: El Zorrito. Periódico satírico y democrático y El Lorito. Periódico satírico y democrático. Ambos criticaron, al igual que Allende, a la burguesía y al clero burgués. Allende tuvo conciencia a fines de siglo del enorme papel que había desempeñado en la formación de un ideal republicano y democrático en el país, a veces superior que el ejercido por la prensa radical como La Ley. Así escribió en 1899: "No debo favores a nadie, no debo un pliego de papel a nadie, y el pueblo chileno es liberal, gracias a mí, y sólo a mí, pues, cuando La Ley vino a la vida, ya el pueblo estaba liberalizado por mí!", Poncio Pilatos, 4.4.1899. 